\title{
Late Prehistoric Migrations from Pottery Composition Analysis in the North Coast of Spain
}

\section{Alfonso Fanjul Peraza*, Mercedes Pérez Bartolomé, Rodrigo Álvarez García, Emilio Muñoz Fernández and Alberto Ceballos Hornero}

Department of Archaeology, University if Oviedo Council, Spain

Submission: April 25, 2019; Published: May 09, 2019

*Corresponding author: Alfonso Fanjul Peraza, Department of Archaeology, University if Oviedo Council, Vallin 49, Limanes. Oviedo. 33199, Spain

\section{Mini Review}

The increasing pottery analysis of different sites and our results provide sufficiently clear enough to give a new perspective to the long-established debate on settlement migration on the north coast of Spain [1-3]. The current traditionally held theory for these periods is based on the idea that migration occurred in protohistoric times on the coastal planes or from coastal regions inland. Conversely, our information provides a radically different scenario demonstrating stable settlement patterns in the Neolithic and Iron Ages and intensive migration of communities in the Chalcolithic and Bronze Ages. At the beginning of these periods, pottery clearly produced on the inland-coast in the Villaviciosa-Piloña region shows the only instances of coastal settlement movement to have been in the opposite direction from that of the long-held view. In the Bronze Age, population mobility was principally from the inland high-mountain valleys toward the coast, as demonstrated by samples at Fonfría, or toward the extensive middle valleys between the coast and high mountains, as shown by those at Entrecueves cave.

In 2016-17, extensive prospecting and exploration of five hundred archaeological sites took place in caves and rock shelters along the coastline of the Bay of Biscay in eastern Asturias [2,4]. The method employed was surface archaeology, with the aim of finding visible material in situ by meticulously examining all surfaces of the caves and rock shelters. Although the project focused primarily on sites with shell middens in a Mesolithic context, at some of the sites we found evidence of occupation in the Neolithic and later periods.

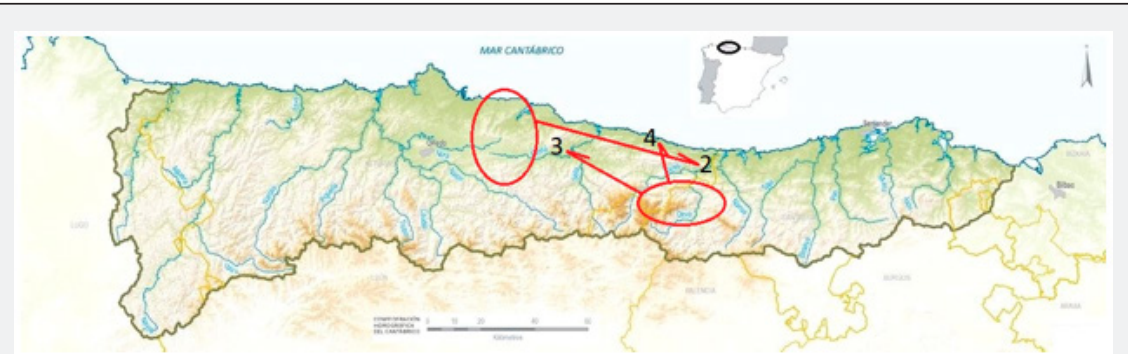

Figure 1: Map showing soil correlations (red) of analysed pottery fragments from the Chalcolithic and Bronze Age sites (black).

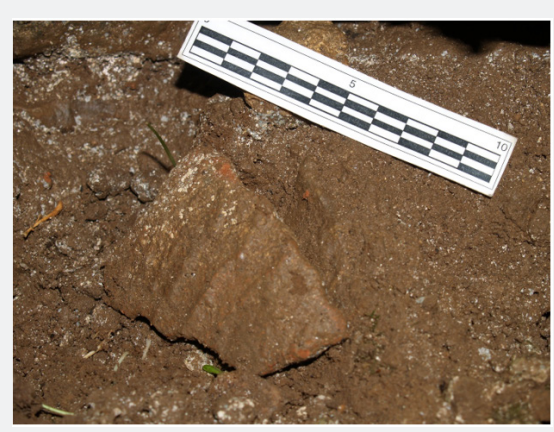

Figure 2: Decorated pottery fragment in situ at Entrecueves cave (Bronze Age). 


\section{Global Journal of Archaeology \& Anthropology}

In order to benefit from the finding of pottery belonging to various pre-historic periods we decided to undertake a detailed analysis of the mineral composition of samples, with a view to gaining information on their possible geographic origin, as well as the manufacturing processes used. To achieve this, we carried out both X-ray fluorescence spectroscopy using a handheld Niton XL3t analyzer and polarized light optical microscopy of a thin section using MLDP Leica equipment in transmission mode [5,6] (Figures 1,2).
Some of the percentages obtained from the mineral analysis of our samples were too low to establish exact geographic location, except in two instances: in the first, unusual anomalies in the mineral content showing strong links to a specific geographic region, other than the find location, led us to clearly identify the material as non-local; in the second, the presence of minerals readily found in the area of the sample, indicated local production (Table 1).

Table 1: local origin was identified by high calcium content and minimal levels.

\begin{tabular}{|c|c|c|c|c|}
\hline No. & Site & Period & Pottery Characteristics & Geographic Links \\
\hline 1 & Andríz, Lledías & Neolithic & $\begin{array}{c}\text { High quartz/limestone } \\
\text { combination }\end{array}$ & Local \\
\hline 2 & Santa María, Vidiago & Chalcolithic & $\begin{array}{c}\text { Low levels of Fe (iron), } \\
\text { Mn (manganese) and Ca } \\
\text { (calcium), inconsistent with } \\
\text { local samples. }\end{array}$ & $\begin{array}{c}\text { Soil belonging to limestone-free eastern- } \\
\text { central Asturias: Villaviciosa-middle Sella } \\
\text { valley, Piloña-Parres. }\end{array}$ \\
\hline 3 & Entrecueves, Parres & Chalcolithic-Bronze Age & $\begin{array}{c}\text { Very high Zn (zinc) content: } \\
30.48 \% \text {. }\end{array}$ & $\begin{array}{c}\text { The very high zinc content, in combination } \\
\text { with other elements (high limestone and } \\
\text { some copper) suggests origin in the upper } \\
\text { Deva-Cares area of the Picos de Europa. }\end{array}$ \\
\hline 5 & $\begin{array}{c}\text { Cueva Nueva, Fonfría, } \\
\text { Niembro }\end{array}$ & Bronze Age & $\begin{array}{c}\text { Very high levels of Ti } \\
\text { (titanium) and Zr (zirconium) } \\
\text { and high levels of Cu (copper) } \\
\text { and Fe (iron) }\end{array}$ & $\begin{array}{c}\text { The combination of coastal sands with Ti } \\
\text { content and significant Zr is only found in the } \\
\text { Cantabrian area of the Picos de Europa. }\end{array}$ \\
\hline 6 & $\begin{array}{c}\text { Lledías, Pueblo Bajo (Puru } \\
\text { Baxu) }\end{array}$ & Iron Age & $\begin{array}{c}\text { Very high Ca with low Cu and } \\
\text { Fe }\end{array}$ & Lecal \\
\hline
\end{tabular}

\begin{tabular}{ll}
\hline \\
Figure 3: Iron Age pottery from Las Torres.
\end{tabular}

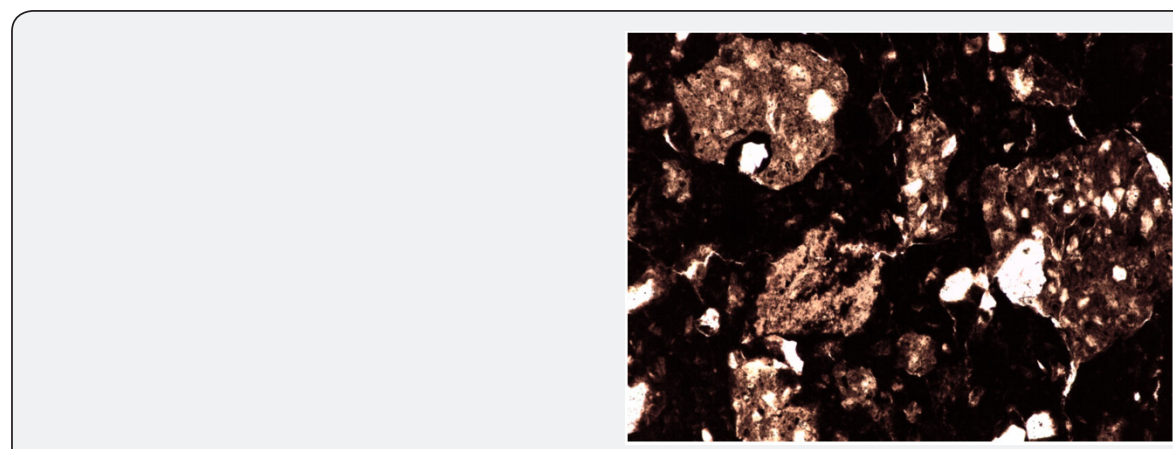

Figure 4: Limestone temper in Neolithic sample from Aldriz.

Clear local origin was identified by high calcium content and minimal levels of other minerals, mainly metals, in the Neolithic and two Iron Age samples, whereas all the Chalcolithic and Bronze Age samples showed content anomalous to local soils. The 
Chalcolithic samples demonstrated their origin in the furthest west inland area of our study region, and those of the Bronze Age showed two correlations that could also be interpreted as evidence of migration by a community transporting their pottery (Figures 3,4).

The shard from Entrecueves cave, situated in a coastal valley, demonstrates its origin in the far inland upper valley of the CaresDeva River in the Picos de Europa mountain range. Interestingly, the shard from Cueva Nueva cave on the coastline demonstrates origin in the same area. This unusual coincidence of samples from the same period found at two such distant sites, allowed us to confirm Bronze Age settlement movement northward from the inland mountainous areas of the region toward the coast.

\section{References}

1. Arias Cabal P (1991) De cazadores a campesinos. La transición al neolítico en la región cantábrica. Universidad de Cantabria. Asamblea Regional de Cantabria: 314. Santander.
2. Fano Martínez MA (1998) El hábitat mesolítico en el Cantábrico occidental. Transformaciones ambientales y medio físico durante el Holoceno antiguo. BAR International. Series, Oxford, UK, 732: 60.

3. Pérez Suárez C (1995) Carta arqueológica de los concejos de Llanes y Rivadedeva (1992). Excavaciones arqueologícas en Asturias 1991-94. Servicio de Publicaciones del Principado de Asturias: 243-245 (243). Oviedo.

4. Pérez Bartolomé M, Muñóz Fernández E, Fanjul Peraza A (2018) Prospecciones arqueológicas en el concejo de Llanes (2016). Excavaciones arqueológicas en Asturias 2013-2016: 537-544.

5. Cubas M (2017) Identifying manufacturing groups trought the mineralogical analysis of prehistoric pottery: The example of the Cantabrian region (North of Spain). Arkeologické rozhledy LXIX: 246260

6. Pérez Bartolomé M, Muñóz Fernández E, Fanjul Peraza A (2018) Prospecciones arqueológicas en el concejo de Ribadesella (2015). Excavaciones arqueológicas en Asturias 2013-2016: 529-536.

\section{Your next submission with Juniper Publishers will reach you the below assets}

- Quality Editorial service

- Swift Peer Review

- Reprints availability

- E-prints Service

- Manuscript Podcast for convenient understanding

- Global attainment for your research

- Manuscript accessibility in different formats

( Pdf, E-pub, Full Text, Audio)

- Unceasing customer service

Track the below URL for one-step submission https://juniperpublishers.com/online-submission.php 